\title{
COLLATERAL REQUIREMENTS FOR SME LOANS: EMPIRICAL EVIDENCE FROM THE VISEGRAD COUNTRIES
}

\author{
Ashiqur RAHMAN ${ }^{1}$, Jaroslav BELAS ${ }^{2}$, Tomas KLIESTIK ${ }^{3}$, Ladislav TYLL ${ }^{4}$ \\ 1,2 Department of Enterprise Economics, Faculty of Management and Economics, \\ Tomas Bata University in Zlin, Mostni 5139, 76001 Zlin, Czech Republic \\ ${ }^{3}$ Faculty of Operation and Economics of Transport and Communications, \\ University of Zilina, Univerzitná 1, 01026 Žilina, Slovakia \\ ${ }^{4}$ Faculty of Business Administration, University of Economics Prague, \\ nám. W. Churchilla 4, 13067 Praha 3, Czech Republic \\ E-mails:1'rahman@fame.utb.cz (correspondingauthor); ${ }^{2}$ belas111@gmail.com; \\ 3tomas.kliestik@fpedas.uniza.sk; 4 ladislav.tyll@vse.cz
}

Received 13 March 2017; accepted 15 July 2017

\begin{abstract}
The purpose of this paper is to examine the determinants of collateral for small and medium enterprises (SMEs) in the context of Visegrad countries: Czech Republic, Slovak Republic, Hungary and Poland. The data set for this paper was obtained from the Business Environment and Enterprise Performance Survey (BEEPS), which was conducted by the World Bank and the European Bank for Reconstruction and Development (EBRD) from 2012-2014. A binary logistic regression model with different specifications was employed to examine the effect of independent variables on the incidence of collateral. The results show that risky borrowers need to pledge collateral and the reduction of asymmetric information can lower the incidence of collateral for SMEs. Moreover, we find that female borrowers are more likely to pledge collateral than male borrowers are. The results also suggest that loans with a longer maturity are more likely to be collateralized than short-term loans. We find evidence that bank-borrower proximity can alleviate the incidence of collateral whereas bank concentration may increase collateral requirements. Policy makers may consider these results to implement policies that can promote bank competition and can lower collateral requirements for female borrowers. The paper contributes to the ongoing debate on the determinants of collateral.
\end{abstract}

Keywords: SME finance, collateral, asymmetric information, bank competition, distance, Visegrad countries.

JEL classification: G21, G32, O16.

\section{Introduction}

Financial constraints on small and medium-sized enterprises (SMEs) are an open scientific research topic for academicians and practitioners due to the immense importance of SMEs to the economic development of a country. Lack of financing availability for SMEs not only hinders new business establishment but also hampers the economic 
growth of countries because of fewer jobs. Ayyagari et al. (2007) found that SMEs contribute about $60 \%$ of jobs in the manufacturing sector in their analysis of 70 developing and developed countries. Beck et al. (2006) state that SMEs report higher financing difficulties than large firms do and the effects of financing obstacles are greater for SMEs.

SMEs face stringent credit conditions from banks because it is contended that SMEs are information opaque and usually cannot produce audited financial statements when they are seeking bank financing (Berger, Udell 2002). Studies based on relationship lending suggest that small firms that engage in long-term relationships with their banks can overcome the asymmetric information problem (Carter et al. 2004; Berger, Udell 2006). However, information generation through relationship lending is costly and, consequently, banks are shy to lend to SMEs (Beck, De La Torre 2007). Due to this information mismatch between lenders and borrowers, commercial banks impose restrictive loan contract terms on SMEs to prevent defaults (Garcia-Teruel et al. 2014). Hence, this asymmetric hidden information may lead to credit rationing because it is difficult for the banks to evaluate the quality of the borrowers (Stiglitz, Weiss 1981). SME business conditions and financial environments are not competitive enough, and therefore SMEs may find it difficult to manage their credit risk properly and thus face strict terms when applying for bank loans (Belas et al. 2015; Lenka et al. 2014).

Imposing collateral requirements on a loan contract is a traditional bank practice to eliminate information opacity and to align the interest of borrowers with the interest of banks (Besanko, Thakor 1987; Boot et al. 1991). Beck et al. (2006), using the World Business Environment Survey (WBES), find that collateral requirements are the third of 12 most important financing obstacles for SMEs. Results from the EBRD and World Bank Business Environment and Enterprise Performance survey (BEEPS) in Eastern Europe and Central Asia indicate that collateral is the fourth most important financing obstacle for external loans. Prior literature suggests that collateral can alleviate adverse selection and moral hazard problems in a loan contract because collateral can act as a signalling device for banks to sort out quality borrowers from risky ones (Bester 1985; Chan, Kanatas 1985; Besanko, Thakor 1987; Boot et al. 1991). Bester (1985) shows that when borrower quality is unknown, banks can use collateral as a screening device to differentiate between good and bad borrowers. In the face of high asymmetric information, quality borrowers may pledge more collateral to show their credit quality by which they can avail loans with lower interest rates because their probability of default is lower (Bester 1985; Chan, Kanatas 1985; Besanko, Thakor 1987). On the contrary, when borrower quality is known and risky, banks will require higher collateral and charge higher interest rates (Jimenez, Saurina 2004; Brick, Palia 2007). This selection of borrowers based on their observable credit quality is known as the observed risk hypothesis. The observed risk hypothesis predicts that banks sort borrowers depending on their risk profile and results in risky borrowers having to pledge collateral and higher interest rates to compensate the risky investment by banks.

The role of collateral as a screening device is prominent in banking studies that find that if collateral minimizes adverse selection, pledging collateral can have a negative relationship with credit risk (Jimenez et al. 2006; Godlewski, Weill 2011). Collateral 
requirements on loan contracts and the observed risk hypothesis have also received utmost attention from researchers. However, these studies are concentrated on a single country and dominated by the US market (Leeth, Scott 1989; Berger, Udell 1990, 2006; Brick, Palia 2007; Han et al. 2009; Berger et al. 2011), with a handful concentrated on the European market (Cowling 1999 - UK; Jimenez, Saurina 2004 - Spain; HernandezCanovas, Martinez-Solano 2006 - Spain; Duarte et al. 2016 - Portugal). There are studies based on cross-country analyses but they cover both developing and developed markets (Godlewski, Weill 2011; Duarte et al. 2017). Although, different authors examined the issue of collateral based lending in different markets, however, it is still an interesting topic for researchers because some loans are provided without any collateral security whereas others require pledging collateral (Steijvers et al. 2010).

In this paper, we focus on Visegrad countries (Czech Republic, Slovak Republic, Hungary, and Poland) to find the determinants of collateral for small business lending. We have purposefully selected Visegrad countries for our research. Because to the best of our knowledge, there is no empirical research that is investigated the issue of collateral based lending in the context of Visegrad countries or in a cross-country European setting. By doing so, we can extend the current state of the literature on collateral requirements for SME loans. Moreover, Visegrad counties are an integral part of European economic system and SMEs in the Visegrad countries contribute the largest portion of employment. Empirical research by Ayyagari et al. (2007) find that SMEs create about $65 \%$ of the jobs in the Czech Republic, 63\% in Poland, 59\% in the Slovak Republic and $46 \%$ in Hungary. Additionally, Daszkiewicz (2014) in his research finds that in 2012, SMEs counted for $99.8 \%$ of enterprises in the Czech Republic and in Poland, similarly, 99.9\% enterprises are counted for SMEs in the context of Slovak Republic and in Hungary, respectively.

Likewise, we are interested in these countries because, during the worldwide financial crisis, business activities of SMEs in the Visegrad countries significantly suffered due to lack of finance from banks (Korab, Pomenkova 2014). Korab and Pomenkova examined pre and post financial crisis period and access to finance for SMEs in the Visegrad countries. They find that SMEs in the Czech Republic and the Slovak Republic show a greater reduction in loans than of the other two countries (Hungary and Poland) and they have a very limited access to finance during the period of financial crisis (2008-2009) in comparison to pre-crisis period (2006-2007). Hence, above studies suggest that in general, SMEs are financial constraints than the large firms and credit market contraction is making it even harder for SMEs to raise external finance for investment.

The European market is significantly different from the US or other market-based systems because in Europe, bank loans are the main source of business financing. According to the Survey on the Access to Finance in the Euro Area (SAFE 2015), 42\% of the SMEs operating in 2012 faced a lack of access to financing and among these SMEs, approximately $74 \%$ reported bank loans as relevant to their capital structure. Furthermore, like other European countries, our examined countries are dominated by SMEs and they have momentous importance for the economic development of the country. Hence, considering the importance of SMEs in our examined countries, finding the determinants 
of collateral can be valuable not only for researchers but also for practitioners to know more about the incidence of collateral during the loan acquisition process.

The rest of the paper is structured as follows. Section 1 provides theoretical and empirical evidence on the incidence of collateral and the factors that affect collateral. Section 2 describes our data set, variables and method. In section 3, we present our results and discussion. The paper concludes with main findings, recommendations and scope for future study.

\section{Collateral-based lending and the determinants of collateral}

Collateral requirements on a loan contract are particularly significant for SMEs compared to large firms because they lack physical assets to pledge as collateral to the banks, which may cause SMEs to be credit rationed (Menkhoff et al. 2006). Additionally, SMEs are owned and managed by individuals and, hence, personal characteristics and private wealth of the borrower can have a greater impact on the business performance of SMEs than large firms (Bolton Committee 1971; Tirole 2010). According to Ang et al. (1995), the influence of the personal wealth of SME borrowers can assist in obtaining bank financing because, at times, personal wealth is inseparable from business assets. In that case, an individual can pledge personal assets as collateral to the banks and obtain financing.

Jensen and Meckling (1976) show that collateral-based lending can generate benefits for the lenders, such as alleviation of the agency problem by which collateral can prevent asset substitution and hold back firms from borrowing excessively. Asset substitution may arise when the borrowing firms divert from their intended projects to other risky projects with anticipated higher returns. Furthermore, Myres (1977) shows that collateral might reduce the underinvestment problem. An underinvestment problem occurs when there is a tendency of managers to invest in risky projects with lower net present value, which reduces the value for shareholders and transfers the wealth to unsecured debt holders. Additionally, Stiglitz and Weiss (1981) report that collateral security can minimize banks' loss exposure and, as a result, it may facilitate easy access to financing by alleviating credit rationing.

Numerous studies show that bank-borrower relationships can lower the collateral requirements for firms. Relationship lending minimizes the information gap and helps banks to predict the quality of projects more accurately, which reduces collateral requirements from borrowers (Degryse, Van Cayseele 2000; Chakraborty, Hu 2006; Gama, Duarte 2015; Rahman et al. 2016). Nonetheless, relationship lending is a labour intensive process and can increase the loan process cost for lending institutions as a result of frequent visits to the firms to acquire soft information (Petersen, Rajan 2002). Furthermore, studies show that relationship lending may instead increase collateral with the duration and scope of a relationship due to a lock-in situation with banks caused by excessive information sharing (Lehmann, Neuberger 2001; Jimenez et al. 2006). Jimenez and Saurina (2004) show that relationship-lending loans are riskier than non-relationship based lending, as relationship lending involves a less restrictive loan screening process 
and increases the default rates. It is argued that the importance of relationship lending in alleviating information asymmetry is decreasing with the use of credit rating models and availability of accounting-based hard information (Petersen, Rajan 2002; Jimenez et al. 2006). Jimenez et al. (2009) find that accounting-based hard information can be a substitute for collateral because it makes the loan screening process more accurate.

As discussed, collateral requirements on loan contracts are quite common in the credit market to align the interest of the borrowers with the interest of the banks. However, there are differences between firms that provide collateral and those that do not. Thus, depending on firm characteristics, collateral requirements can differ and are a main area of empirical study of this paper. Moreover, based on loan characteristics (loan size, maturity and interest rates) collateral requirements may vary, as different categories of loans might have idiosyncratic risk classifications. Additionally, credit market imperfections can have a significant impact on the incidence of collateral because not all markets are competitive or efficient enough to remove anomalies in the loan market. The situation is worsened by the distance between lenders and borrowers. Distance makes it more difficult for lenders to justify the viability of borrowers' projects (Petersen, Rajan 2002), which can impose collateral burdens for more distant borrowers (Jimenez et al. 2006). Thus, in this paper, we would like to evaluate the effect of firm characteristics, loan characteristics and market characteristics on the incidence of collateral.

\subsection{Firm characteristics}

Information asymmetry is one of the main problems faced by SMEs when seeking bank loans because they cannot show their credit quality. This limited information about the SMEs create barriers in accessing bank financing and, hence, banks impose different credit restrictions on SME loans to overcome this asymmetric information problem, for example, collateral, high interest rates, shorter maturity and covenants. Scholars frequently use firm size and age as inverse proxies for information asymmetry in SME lending and find that information transparency reduces collateral requirement. In this paper, we examine the impact of asymmetric information on the incidence of collateral with four inverse proxies for information asymmetry (firm size, age, audited financial statement and asset tangibility).

In terms of firm size it is argued that the large firms can demonstrate a consistent past business history, thus making it easier for banks to evaluate their credit quality (Knyazeva, A., Knyazeva, D. 2012). Hence, increased information transparency can lower the incidence of collateral. A study by Grunert and Norden (2012) shows that large firms pledge less collateral because they have more bargaining power and can borrow from different sources with better credit terms. Menkhoff et al. (2006) show that younger firms need to provide more collateral for bank loans, as they are considered unstable. Similarly, Chakraborty and $\mathrm{Hu}$ (2006) find that older firms are more transparent than smaller ones, resulting in older firms pledging lower collateral.

Berger and Udell (2002) report that SMEs suffer from information asymmetry due to lack of availability of audited financial statements, which may cause SMEs to be credit rationed. Ferri and Murro (2015) find that audited financial statements can minimize 
information asymmetry and influence easy access to finance. Similarly, a research by Leon (2015) from 69 developing countries finds that firms having audited financial statements are more transparent and it is easier for them to access loans from external lenders. Considering the above studies from the point of view of access to finance, it may be possible to say that having audited financial statements may reduce information asymmetry and that may lessen collateral burden to SMEs. In contrary, audit reports may also increase collateral requirements for firms, as information transparency allows banks to evaluate the firm more accurately, which can result in higher collateral requirements depending on the credit quality of the firm. Therefore, we can expect both positive and negative effects of audited financial statements on collateral. Additionally, firms with tangible assets have more information transparency than those of the service, retail or innovation oriented business sectors, making it easier for lenders to assess their credit risk (Gompers 1995). A. Knyazeva and D. Knyazeva (2012) find that firms with asset tangibility receive loans with lower interest rates; they argue that asset tangibility signals easy loan recovery in the event of default. In this regard, we may argue that as manufacturing firms have more tangible assets than other business types, they may pledge lower collateral due to greater information transparency.

According to the agency theory, firms with more concentrated ownership and those owned and managed by the same person have minimum or, at times, zero agency costs (Jensen, Meckling 1976; Fama, Jensen 1983). Ang (1992) shows that firms with concentrated ownership tend to have long-term orientations and strive for survival and reputation, therefore, less agency related conflicts. Moreover, it is difficult to enforce loan recovery if several people own the firm (Hanedar et al. 2014). Hanedar et al. find that sole ownership firms pledge lower collateral than of the corporations. It is possible that firms with less concentration would make enforcement weaker, thus increasing collateral requirements. Therefore, we expect to find a negative relationship between ownership concentration and collateral pledges.

Borrower experience and gender is also considered as important determinants of collateral-based lending. Hsiao and Chou (2015) show that experienced borrowers can manage businesses more efficiently than inexperienced borrowers manage and minimize the credit risk of loans. Neuberger and Rathke-Doppner (2015) find that younger borrowers pledge higher collateral due to the lack of business experience compared to older, more experienced borrowers. Grunert and Norden (2012) argue that a skilled and experienced borrower has more bargaining power with banks and, therefore, it is possible to relax strict credit terms such as interest rate. At the same time, experienced managers of older firms can prepare better loan proposals and use their past business track records to lower collateral requirements (Berger, Udell 1995). Considering the above arguments, it is more likely that an experienced borrower may use his/her bargaining power and previous skills to minimize strict credit terms and collateral requirements on loan contracts. However, Duarte et al. (2017) did not find any statistically significant effects of borrower experience on collateral.

Studies show that because of sexual stereotyping and gender discrimination, femaleowned firms face stricter credit conditions from banks compared to male-owned firms 
(Carter, Rosa 1998). Boyer and Blazy (2014) find that default rates are higher for women-owned firms than those that are male owned. Moreover, Garwe and Fatoki (2012) find that female-owned firms have difficulty in accessing financing because they lack sufficient management skills. Alesina et al. (2013) find that women-owned firms in Italy pay higher interest rates than male-owned firms. Thus, it is possible that banks assume that women-owned firms are risky. Therefore, we expect to find a positive relationship between female ownership of firms and pledge of collateral. Belluchi et al. (2010) find that SMEs owned by female borrowers in Italy are required to provide higher collateral, which increases financial barriers on women-led SMEs.

A widespread collection of studies report that innovative firms encounter strict credit conditions in the form of credit rationing, lower maturity of loans and higher collateral requirements compared to non-innovative firms because innovative firms are more information opaque (Freel 2007; Lee et al. 2015). Additionally, it is difficult to demonstrate the quality of innovative projects due to intellectual properties concerning innovation activities (Hall 2010). Moreover, Moore and Garnsey (1993) contend that it is difficult to measure returns from innovation activities and estimate cash flows with any precession. Considering the above theories related to innovative firms and financing, we assume that innovative firms may pledge more collateral in compared to non-innovative firms because of uncertainties in their capital commitment as well as higher asymmetric information.

Prior studies on the observed risk hypothesis suggest that when the quality of the borrower is known and risky, more collateral is required due to the higher credit risk of the loan. Hanedar et al. (2014) used liquidity risk, overdue payments and crime as proxies for borrower risk and found that these factors have a positive correlation with the presence of collateral. Jimenez et al. (2006) used borrower loan defaults as observed risk proxies in the Spanish market and found that loan defaults have a positive correlation with collateral, thus supporting the observed risk hypothesis. Moreover, the quality of the firm is measured through the availability of international quality recognition, such as ISO certification. Availability of such certification indicates higher firm quality (Hanedar et al. 2014). In this paper, we used liquidity risk, crime and ISO certification as proxies for borrower observed credit quality and expect to find a positive relationship between liquidity risk and crime with collateral and a negative relationship with ISO certification.

\subsection{Loan characteristics}

Studies on collateral-based lending suggest that loan size and duration significantly affect the presence of collateral. Large loans are usually secured because of the high-risk perception (Godlewski, Weill 2011). Moreover, a large loan increases the leverage of a firm and may increase the likelihood of default (Leeth, Scott 1989; Avery et al. 1998). Hence, it is important for banks to secure loans by asking for collateral from borrowers (Degryse, Van Cayseele 2000). Voordeckers and Steijvers (2006) also find that large loans are collateralized, whereas Hernandez-Canovas and Martinez-Solano (2006) show that small loans are usually provided based on the relationship between the bank and the borrower. 
With respect to loan maturity, long-term loans are riskier than short-term loans. Longterm loans may induce moral hazards and adverse selection problems due to the longer loan period and, hence, loan maturity is positively correlated to collateral (Harhoff, Korting 1998; Voordeckers, Steijvers 2006; Hainz et al. 2013; Duarte et al. 2017). Additionally, longer periods may induce borrowers to shift from less risky to high-risk projects (Jensen, Meckling 1976). Shorter loan maturity can control borrowers' risk shifting behaviour by minimizing the moral hazard problem (Knyazeva, A., Knyazeva, D. 2012).

Researchers frequently measure the observed risk hypothesis and validate the adverse selection theory using the relationship between loan spread and collateral. When borrower quality is observable as risky, borrowers need to provide more collateral and need to incur higher interest rates (Bester 1985; Besanko, Thankor 1987). Brick and Palia (2007) find that loans secured with collateral need to afford 200-400 basis points higher interest rates than the non-secured loans. Berger and Udell (1990) suggest that risky borrowers need to provide collateral and are charged higher interest rates. Therefore, according to the observed risk hypothesis, we expect to find a positive relationship between collateral and interest rates. Regarding the adverse selection hypothesis, quality borrowers may provide more collateral to obtain loans with lower interest rates through signalling their superior credit quality; hence, collateral acts as a substitute for lower interest rates (Bester 1985; Besanko, Thakor 1987). Degryse and Van Cayseely (2000) find a negative relationship between interest rates and collateral, supporting the adverse selection theory. Godlewski and Weill (2011) argue that both the adverse selection and observed-risk hypotheses can be validated depending on the degree of information asymmetry in the loan market. However, they also find strong support for the observed-risk hypothesis and borrower quality.

\subsection{Lender market characteristics}

Bank competition and concentration is widely used in banking studies to determine their impact on collateral requirements. Berlin and Butler (2002) argue that as competition in the market intensifies, lenders need to relax lending terms, for example, lower expected collateral ratios due to less market power. Voordeckers and Steijvers (2006) find that bank competition reduces collateral requirements because borrowers can switch to other banks to obtain loans with better lending terms. Conversely, Jimenez et al. (2009) find that in a competitive market, banks can increase collateral ratios in an attempt to increase their superiority over competitors in a loan contract. Hainz et al. (2013) report that requiring collateral in a loan contract is more likely when the market is less competitive, the assumption is that competition and concentration is negatively associated. Jimenez et al. (2006) find that bank concentration is negatively correlated with collateral. In a concentrated market, a bank can use its market power to attract quality borrowers more efficiently than in a competitive market.

Bank-borrower distance is also a significant determinant of collateral requirements in a loan contract. Berger and Udell (2002) in their theoretical model showed that soft information collection is critical in SME lending and is obtained by continuous interaction with borrowers. However, the cost of collecting site-specific soft information about the borrower increases with the distance between bank and borrower (Petersen, 
Rajan 2002). Therefore, banks choose between their most cost-efficient options, such as screening the borrower or asking for collateral to alleviate organizational diseconomies (Manove et al. 2001). Jimenez et al. (2009) find that lenders ask for more collateral from local borrowers, whereas distant borrowers pledge lower collateral. They argue that banks conduct strict credit screening processes while lending to a distant borrower, which reduces the incidence of collateral. A later study by Hainz et al. (2013) shows that loans granted to distant borrowers are more likely to be collateralized than loans granted to local borrowers. It is argued that local lenders have superior information about firms closer to the bank and, as a result, it is easier for local lenders to evaluate the credit risk of the firms. Regardless of these studies, the effect of distance on collateral requirements is still inconclusive and in this paper, we show new evidence from the Visegrad countries.

A summary of collateral based studies concentrated on the firm characteristics, loan characteristics and lender market characteristics in different countries are presented in the following table.

Table 1. A summary of studies based on firm characteristics, loan characteristics, and lender market characteristics and their impact on collateral requirements on SMEs

\begin{tabular}{|c|c|c|c|}
\hline Study & Country & Variable & Results \\
\hline $\begin{array}{l}\text { Knyazeva A. } \\
\text { and Knyazeva D. } \\
(2012)\end{array}$ & USA & Firm size & $\begin{array}{l}\text { Large firms pledge less collateral due to } \\
\text { better information quality. }\end{array}$ \\
\hline $\begin{array}{l}\text { Grunert and } \\
\text { Norden }(2012)\end{array}$ & $\begin{array}{l}\text { USA \& } \\
\text { Germany }\end{array}$ & Firm size & $\begin{array}{l}\text { Large firms pledge less collateral because } \\
\text { of more bargaining power. }\end{array}$ \\
\hline $\begin{array}{l}\text { Chakraborty and } \\
\text { Hu (2006) }\end{array}$ & USA & Firm age & $\begin{array}{l}\text { Firm age has a negative impact on } \\
\text { collateral. }\end{array}$ \\
\hline $\begin{array}{l}\text { Menkhoff et al. } \\
\text { (2012) }\end{array}$ & Thailand & Firm age & $\begin{array}{l}\text { Younger firms need to pledge higher } \\
\text { amounts of collateral than of the older } \\
\text { firms. }\end{array}$ \\
\hline Gompers (1995) & USA & Asset tangibility & $\begin{array}{l}\text { Asset tangibility has a negative effect on } \\
\text { collateral. }\end{array}$ \\
\hline $\begin{array}{l}\text { Hanedar et al. } \\
\text { (2014) }\end{array}$ & $\begin{array}{l}27 \text { transition } \\
\text { countries }\end{array}$ & $\begin{array}{l}\text { Ownership } \\
\text { structure as } \\
\text { a measure of } \\
\text { agency costs }\end{array}$ & $\begin{array}{l}\text { Ownership concentration has a negative } \\
\text { effect on collateral. }\end{array}$ \\
\hline $\begin{array}{l}\text { Steijvers et al. } \\
\text { (2010) }\end{array}$ & USA & $\begin{array}{l}\text { Family and } \\
\text { non-family firms } \\
\text { as proxies for } \\
\text { agency costs }\end{array}$ & $\begin{array}{l}\text { Family firms pledge more collateral due to } \\
\text { agency issues. }\end{array}$ \\
\hline $\begin{array}{l}\text { Neuberger and } \\
\text { Rathke-Doppner } \\
\text { (2015) }\end{array}$ & Germany & $\begin{array}{l}\text { Borrower } \\
\text { experience }\end{array}$ & $\begin{array}{l}\text { Experienced borrowers pledge less } \\
\text { collateral. }\end{array}$ \\
\hline
\end{tabular}


End of Table 1

\begin{tabular}{|c|c|c|c|}
\hline Study & Country & Variable & Results \\
\hline $\begin{array}{l}\text { Berger and Udell } \\
(1995)\end{array}$ & USA & $\begin{array}{l}\text { Borrower } \\
\text { experience }\end{array}$ & Negative effect on collateral. \\
\hline $\begin{array}{l}\text { Duarte et al. } \\
(2017)\end{array}$ & $\begin{array}{l}29 \text { developed } \\
\text { and emerging } \\
\text { countries }\end{array}$ & $\begin{array}{l}\text { Borrower } \\
\text { experience }\end{array}$ & $\begin{array}{l}\text { Borrowers experience has no effect } \\
\text { on collateral. }\end{array}$ \\
\hline $\begin{array}{l}\text { Belluchi et al. } \\
(2010)\end{array}$ & Italy & $\begin{array}{l}\text { Borrower gender } \\
\text { (female) }\end{array}$ & $\begin{array}{l}\text { Female borrowers provide more collateral } \\
\text { than the male borrowers do. }\end{array}$ \\
\hline $\begin{array}{l}\text { Hanedar et al. } \\
(2014)\end{array}$ & $\begin{array}{l}27 \text { transition } \\
\text { countries }\end{array}$ & $\begin{array}{l}\text { Borrower } \\
\text { observed risk }\end{array}$ & $\begin{array}{l}\text { Risky borrowers need to pledge collateral } \\
\text { on their loan application. }\end{array}$ \\
\hline $\begin{array}{l}\text { Godlewski and } \\
\text { Weill (2011) }\end{array}$ & $\begin{array}{l}31 \text { developing } \\
\text { and developed } \\
\text { countries }\end{array}$ & $\begin{array}{l}\text { Borrower } \\
\text { observed risk }\end{array}$ & $\begin{array}{l}\text { Borrower observed risk profile has a } \\
\text { positive effect on collateral. }\end{array}$ \\
\hline $\begin{array}{l}\text { Leeth and Scott } \\
\text { (1989) }\end{array}$ & USA & Loan size & $\begin{array}{l}\text { Large loans are secured due to high-risk } \\
\text { perception by the banks. }\end{array}$ \\
\hline $\begin{array}{l}\text { Voordeckers and } \\
\text { Steijvers (2006) }\end{array}$ & Belgium & Loan size & Positive effect on collateral. \\
\hline $\begin{array}{l}\text { Hernandez- } \\
\text { Canovas and } \\
\text { Martinez-Solano } \\
(2006)\end{array}$ & Spain & Loan size & $\begin{array}{l}\text { Small loans are based on relationship } \\
\text { lending. }\end{array}$ \\
\hline $\begin{array}{l}\text { Harhoff and } \\
\text { Korting (1998) }\end{array}$ & Germany & Loan maturity & $\begin{array}{l}\text { Long-terms loans are provided with } \\
\text { collateral security. }\end{array}$ \\
\hline $\begin{array}{l}\text { Voordeckers and } \\
\text { Steijvers (2006) }\end{array}$ & Belgium & Loan maturity & $\begin{array}{l}\text { Longer maturity has a positive relationship } \\
\text { with collateral. }\end{array}$ \\
\hline $\begin{array}{l}\text { Duarte et al. } \\
(2016)\end{array}$ & Portugal & Loan maturity & $\begin{array}{l}\text { Long-term loans are collateralized due } \\
\text { to moral hazard issue. }\end{array}$ \\
\hline $\begin{array}{l}\text { Besanko and } \\
\text { Thakor (1987) }\end{array}$ & USA & Loan interest rate & Positive impact on collateral. \\
\hline $\begin{array}{l}\text { Brick and Palia } \\
(2007)\end{array}$ & USA & Loan interest rate & $\begin{array}{l}\text { Positive results on collateral due to } \\
\text { borrower observed-risk profile. }\end{array}$ \\
\hline $\begin{array}{l}\text { Voordeckers and } \\
\text { Steijvers }(2006)\end{array}$ & Belgium & Bank competition & $\begin{array}{l}\text { Negative effect on collateral because of } \\
\text { other competitors and less holding power. }\end{array}$ \\
\hline $\begin{array}{l}\text { Jimenez et al. } \\
(2009)\end{array}$ & Spain & Bank competition & $\begin{array}{l}\text { Banks would like to create their } \\
\text { superiority over other lenders by taking } \\
\text { collateral. Hence, positive effect on } \\
\text { collateral. }\end{array}$ \\
\hline Hainz et al. (2013) & $\begin{array}{l}70 \text { developed } \\
\text { and } \\
\text { developing } \\
\text { countries }\end{array}$ & $\begin{array}{l}\text { Bank } \\
\text { concentration }\end{array}$ & Positive results on collateral. \\
\hline $\begin{array}{l}\text { Jimenez et al. } \\
(2009)\end{array}$ & Spain & $\begin{array}{l}\text { Bank-Borrower } \\
\text { distance }\end{array}$ & $\begin{array}{l}\text { Local borrowers pledge more collateral } \\
\text { than the distant ones. }\end{array}$ \\
\hline Hainz et al. (2013) & $\begin{array}{l}70 \text { developed } \\
\text { and } \\
\text { developing } \\
\text { countries }\end{array}$ & $\begin{array}{l}\text { Bank-Borrower } \\
\text { distance }\end{array}$ & $\begin{array}{l}\text { Distance borrowers pledge higher } \\
\text { collateral. }\end{array}$ \\
\hline
\end{tabular}




\section{Data, method and variables}

\subsection{Data}

The data set we used for our analysis was obtained from the latest version of the BEEPS V survey, which was a joint project of the European Bank for Reconstruction and Development (EBRD) and the World Bank (WB) conducted from 2012-2014. The BEEPS survey was first conducted in 1999 in 26 countries by covering about 4000 firms. The latest version of the BEEPS survey was completed in 30 transition economies, including Russia, to examine the business environment conditions of the enterprises. The data set covers 15,883 enterprises that include micro, small, medium and large firms. All firms' related variables are obtained from the BEEPS survey and to examine the effect of bank market structure on collateral we included data from the Beck et al. (2000), Global Financial Database.

The BEEPS data set covers 254 firms in the Czech Republic, 268 firms in the Slovak Republic, 542 firms in Poland and 310 firms in Hungary. However, as the aim of this paper is to examine collateral requirements in the segment of SMEs only, we eliminated non-SME firms. We have defined SMEs according to the conventions of both OECD and BEEPS as firms with less than 250 employees. By doing so, we obtained 239 firms in the Czech Republic, 260 in the Slovak Republic, 518 in Poland and 294 firms in Hungary, totalling 1,311 SMEs for our descriptive analysis. Among these 1,311 SMEs, 492 firms had loan information with collateral requirements.

\subsection{Method and variables}

The aim of this paper is to find the determinants of collateral. Collateral is a binary dependent variable, which indicates its presence in a loan contract. Considering the nature of our dependent variable, we employed logit regressions for our analysis following Hainz et al. (2013), Jimenez et al. (2006) and Berger et al. (2011). Our full empirical model is as follows:

$$
\begin{aligned}
& \operatorname{Pr}(\text { Collateral }=1)=\beta_{1} \text { firm characteristics }+\beta_{2} \text { loan characteristics }+ \\
& \beta_{3} \text { lender market characteristics }+\varepsilon_{i},
\end{aligned}
$$

where Collateral is a binary dependent variable that takes a value of one if the loan is collateralized, and zero otherwise. $\varepsilon_{i}$ is the usual error term. Moreover, $\beta_{1}$ firm characteristics, $\beta_{2}$ loan characteristics, and $\beta_{3}$ lender market characteristics are set of independent variables to determine their impact on our dependent variable $($ Collateral $=1)$.

\subsubsection{Independent variables}

To examine our model on the incidence of collateral, we group our independent variables into three categories: firm-specific, loan-specific and lender market characteristics. In Table 2, we present a definition and source for each variable.

With respect to the first group of firm-specific factors, we examine four inverse proxies for information asymmetry: Size (number of full-time employees), Age (number of years the firm has been operating), Audit ( 1 if external auditors check the firm financial 
statement, and 0 otherwise) (Berger, Udell 2002; Chakraborty, Hu 2006; Ortiz-Molina, Penas 2008; Menkhoff et al. 2012; Duarte et al. 2017). By following the related studies, we also consider firm size, age, audit report as inverse proxies for information opacity, and expect to find a negative association with collateral. To examine the effect of asset tangibility in minimizing information asymmetry, we include Manufacturing firms ( 1 if the firm is a manufacturing firm and 0 otherwise) (Gompers 1995). To examine the impact of agency costs in collateral requirements (Hanedar et al. 2014), our model includes Ownership concentration (percentage ownership of the firm held by the largest shareholder). As discussed elsewhere, ownership concentration may have a negative effect on collateral requirements due to less agency related issues, since the owner is most likely the manager of the firm's. To examine the effect of borrower experience in collateral based lending, we include Experience (years of experience of the top manager) (Duarte et al. 2017). To measure gender-based discrimination in collateral based lending, we include Female ( 1 if one of the firm owners is female, and 0 otherwise). Empirical research finds that female owners face greater restrictions from banks (Belluchi et al. 2010). To examine financial constraints on innovative firms in the form of higher collateral, we include Innovation (1 if the firm introduced new products or services during last three years, and 0 otherwise). Finally, to measure the borrower observed-risk hypothesis, we examine three proxies for borrower risk: Quality, Crime and Liquidity. Quality is 1 if the firm has an internationally recognized quality certificate, and 0 otherwise. Crime is 1 if the firm has experienced any losses because of theft, robbery, vandalism or arson, and 0 otherwise (Hanedar et al. 2014; Duarte et al. 2017). Liquidity measures the percentage of credit sales over total sales, as more credit sales can increase the possibility of liquidity crisis (Hanedar et al. 2014). These above studies argue that firms observed risk profile could have a positive impact on collateral.

To examine the impact of loan characteristics and the presence of collateral, we estimate three loan-specific variables: LoanSize, LoanMaturity and InterestRate. LoanSize is loan amount in dollars (Godlewski, Weill 2011), LoanMaturity is loan duration in months (Jimenez et al. 2006) and InterestRate is the annual cost of the loan in percentage (Hanedar et al. 2014). According to the moral hazard theory, we expect to find a positive relationship between loan size and loan maturity with the presence of collateral. However, as discussed earlier with interest rates, we can validate both the adverse selection and observed-risk hypotheses.

This paper examines three lender market characteristics and their impact on the presence of collateral. City is 1 if the firm is located in the capital city, and 0 otherwise (Hanedar et al. 2014). City is included in the analysis because it is expected that firms located in the capital city may experience lower collateral requirements from banks, as the capital city is usually the financial hub of the country and, hence, distance will be lower between the banks and borrowers. BRc (number of bank branches per 100,000 adults) (Duarte et al. 2017) is also included as a proxy for bank-borrower proximity (inverse to distance). We expect to find a negative relationship between number of bank branches and collateral. As increased number of bank branches may reduce bankborrower distance and that may increase information collection efficiency, it may lead 
to a reduction of dependency on collateral. Finally, yet importantly, as an inverse proxy to bank competition, we included $C R$ (asset share of the largest three banks in total banking system assets) (Hanedar et al. 2014). If the market is highly concentrated, we may find a positive relationship between concentration and the incidence of collateral. Detailed selection of variables can also be seen in Table 1.

Table 2. Definition and sources of variables

\begin{tabular}{|c|c|c|}
\hline Variable & Definition & Source \\
\hline Collateral & $\begin{array}{l}\text { Equals } 1 \text { if the firm has pledged collateral to obtain an } \\
\text { external loan }(0,1)\end{array}$ & BEEPS \\
\hline \multicolumn{3}{|c|}{ Firm characteristics } \\
\hline Age & $\begin{array}{l}\text { Age of firm, measured as the number of years that the firm } \\
\text { has been operating }\end{array}$ & BEEPS \\
\hline Size & $\begin{array}{l}\text { Size of the firm, measured as the number of full-time } \\
\text { employees }\end{array}$ & BEEPS \\
\hline Audit & $\begin{array}{l}\text { Equals } 1 \text { if the firm financial statement is checked by } \\
\text { external auditors }(0,1)\end{array}$ & BEEPS \\
\hline Manufacturing & Equals 1 if the firm is a manufacturing firm $(0,1)$ & BEEPS \\
\hline Ownership & $\begin{array}{l}\text { Percentage ownership of the firm held by the largest } \\
\text { shareholder }\end{array}$ & BEEPS \\
\hline Experience & Experience of top manager measured in years & BEEPS \\
\hline Female & Equals 1 if one of the firm owners is female $(0,1)$ & BEEPS \\
\hline Quality & $\begin{array}{l}\text { Equals } 1 \text { if the firm has an internationally recognized quality } \\
\text { certification }(0,1)\end{array}$ & BEEPS \\
\hline Innovation & $\begin{array}{l}\text { Equals } 1 \text { if the firm has introduced any new products within } \\
\text { the last three years }\end{array}$ & BEEPS \\
\hline Crime & $\begin{array}{l}\text { Equals } 1 \text { if the firm has experienced any losses as a result of } \\
\text { theft, robbery, vandalism or arson }(0,1)\end{array}$ & BEEPS \\
\hline Liquidity & Credit sales over total sales (\%) & BEEPS \\
\hline \multicolumn{3}{|c|}{ Loan characteristics } \\
\hline LoanSize & Loan amount measured in US dollars & BEEPS \\
\hline LoanMaturity & Loan duration in months & BEEPS \\
\hline InterestRate & Loan annual cost $(\%)$ & BEEPS \\
\hline \multicolumn{3}{|c|}{ Lender market characteristics } \\
\hline City & Equals 1 if the firm is located in the capital city $(0,1)$ & BEEPS \\
\hline CR & $\begin{array}{l}\text { The asset share of the three largest banks in total banking } \\
\text { system assets }\end{array}$ & Beck et al. (2000) \\
\hline $\mathrm{BRc}$ & Number of bank branches per 100,000 adults & Beck et al. (2000) \\
\hline
\end{tabular}

Note: This table presents variable definitions and sources of the data set. BEEPS = Business Environment and Enterprise Performance Survey. 


\section{Results}

\subsection{Descriptive statistics}

Table 3 presents the results of descriptive statistics for our full sample of firm and also shows country-level segmentation. With respect to all firms, 432 had collateral information and about $70 \%$ of the SMEs pledged Collateral for their most recent loans. Thus, the preliminary data suggests that pledging collateral is quite common for SMEs in the Visegrad countries. It is not surprising that only $34 \%$ have financial statements verified by external auditors (Audit). This result also supports the existing literature that SMEs usually cannot produce audited financial statements, which we have already discussed. Descriptive statistics also suggest that firm structure in our sample possesses a high concentrated ownership pattern (mean of Ownership is 77\%). We can also see that about $40 \%$ of the firms have at least one owner who is female (Female) and 19\% reported that they incurred losses due to theft, robbery or vandalism. Moreover, it is noticeable from table 2 that only $31 \%$ of the SMEs conduct innovation activities, which suggests SMEs are reluctant to develop new products or make any changes in their existing product lines.

With respect to loan characteristics, LoanMaturity ranges from 1 month to 300 months, which suggests a huge dispersion between loan maturities. Considering the InterestRate, on average, firms pay about $8.5 \%$ on their borrowings. However, the maximum loan cost is about $70 \%$, indicating that, at times, SMEs pay an extremely high cost for loans.

Variables regarding lender market characteristics suggest that about $19 \%$ of firms are located in the capital city (City), implying that firms in our sample countries are geographically distributed rather than concentrated in the capital. The average number of bank branches $(B R c)$ per 100,000 adults is 26 and ranges from 15 to 32 branches in our sample countries. A higher number of bank branches indicate less distance between the banks and borrowers, which reduces bank organizational diseconomies in the loan screening process. Finally, the mean value of $C R$ is about $73 \%$, suggesting that the banking industry in our sample countries is highly concentrated.

In our country level segmentation, the survey result suggests that $75 \%$ of firms in the Czech Republic and 76\% in the Slovak Republic and Hungary pledged collateral (Collateral) on their loan. However, only $56 \%$ of firms in Poland pledged collateral on their loans. Regarding audit reports, $47 \%$ of firms in the Czech Republic and Slovak Republic have audit reports (Audit) and 46\% of firms in Hungary have their statements audited. However, only $15 \%$ of firms in Poland have audited their financial statements. The survey result also suggests that ownership structure of firms in the Czech Republic are highly concentrated (Ownership about 84\%), which is highest among the countries. Descriptive statistics also highlight that firm-level innovation is lowest in Slovak firms $(18 \%)$, whereas about $50 \%$ of the SMEs in the Czech Republic reported that they have introduced new products during the last three years excluding the year when the survey was conducted. Surprisingly, 36\% of firms in the Czech Republic (highest) reported that they had experienced losses due to theft, vandalism or arson (Crime), whereas only $12 \%$ of firms in Hungary (lowest) reported they had losses due to criminal activities. 


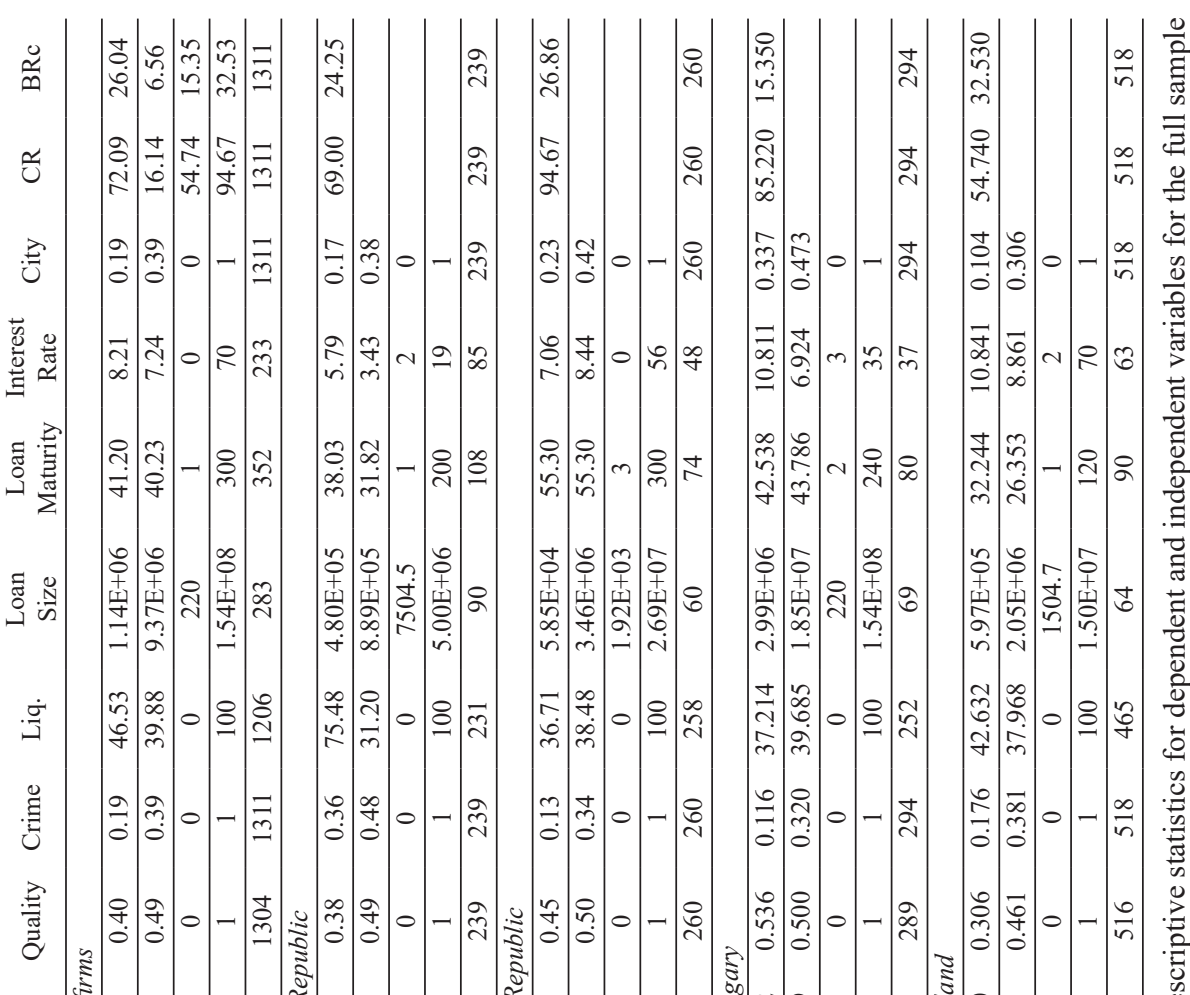

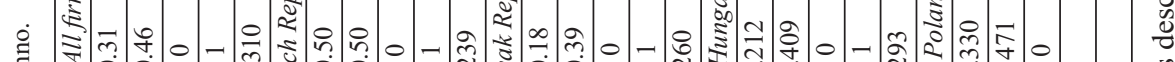



焉

กิ:

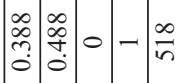

$\frac{0}{\frac{0}{0}}$

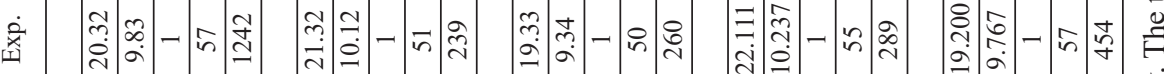

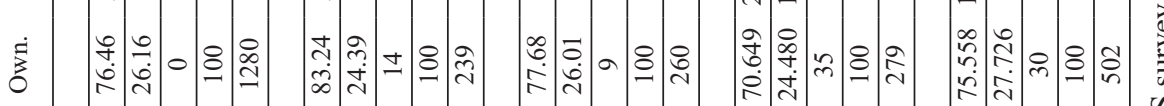

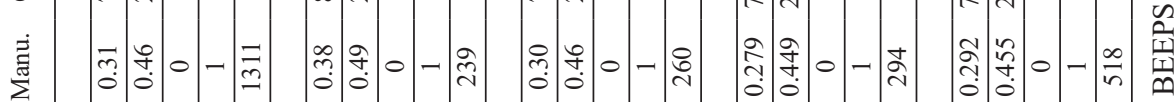

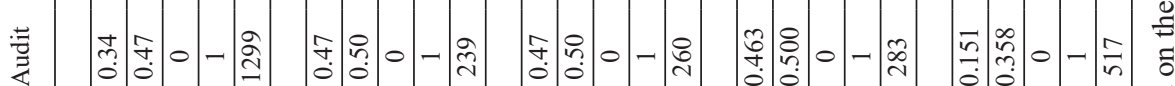

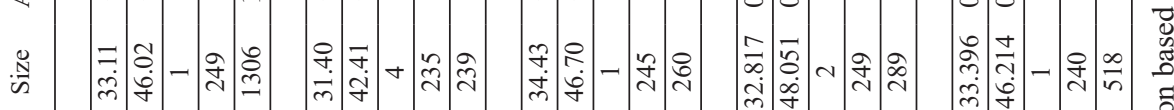

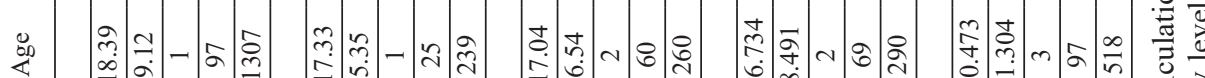

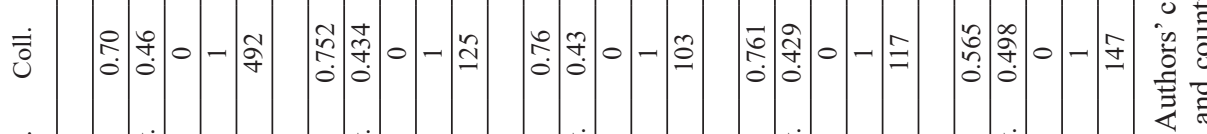

离 
Considering InterestRate, firms in the Czech Republic pay the lowest interest rates (mean interest rate is $5.79 \%$ ), whereas interest rates are highest in Poland (mean interest rate is $10.84 \%$ ). Results regarding bank concentration (CR) suggest that the banking industry is extremely concentrated in the Slovak Republic (94.67\%) and Hungary $(85.22 \%)$. It signals that banks in these countries may use their market power to increase financial constraints to SMEs.

\subsection{Empirical results and discussion}

In Table 4, we present logit regressions results on the incidence of collateral. We estimate three regressions by using different sets of independent and control variables for our analysis. The first regression reports all firm characteristics and their impact on the presence of collateral. The second regression includes all loan characteristics with firm characteristics. The third regression reports all lender market characteristics along with firm characteristics excluding loan characteristics.

Regarding the firm-level determinants of collateral, we find that firm size (Size) has a positive effect on collateral. However, we find a negative relationship between firm age (Age) and collateral. The positive coefficients of firm size with collateral did not meet our expectation. We hypothesized that large firms are more information transparent than the smaller ones, which may help the large firms to avail loans with lower collateral requirements. Nevertheless, our result suggests that large firms pledge more collateral compared to smaller firms. This result is similar to those of Hanedar et al. (2014) and Steijvers et al. (2010). It can be that larger firms prefer to demonstrate credit quality by providing more collateral. Hence, collateral can act as a signalling device for the large firms by which it could be possible that they can lower the loan interest rates. On the other hand, it is also possible that number of employees, as a measure of firm size may not be appropriate to determine the incidence of collateral. A firm can have many employees but may still lack audited financial statements or unable to show satisfactory business information to the bank to minimize information asymmetry that can reduce the incidence of collateral. The negative coefficients of firm age (Age) and collateral suggest that mature firms pledge less collateral than the younger firms do. This result is in line with our expectation and corroborates with the findings of Chakraborty and $\mathrm{Hu}$ (2006); Hanedar et al. (2014) and Duarte et al. (2017). As prior studies suggest, it is easier for the older firms to show past business information, thus reducing collateral requirements. Furthermore, according to relationship lending theory, older firms can engage in long-term relationships with their banks that can reduce collateral for small businesses (Berger, Udell 1995).

With respect to audit report (Audit), we did not find that audited financial statements had any significant effect on collateral requirements. It could be that audit reports may not reflect the overall business condition of firms, and therefore banks do not consider audit reports as sufficient information asymmetry tools for collateral-free loans. The negative coefficient of manufacturing (Manufacturing) firms and collateral suggests that firms with more tangible assets pledge lower collateral than other types of firms. Hence, our result supports the idea that manufacturing firms can show greater information trans- 
parency than firms with fewer tangible assets. It could be the fact that asset tangibility can increase bank efficiency in evaluating the credit risk of firms, making it easier for banks to recover loans by liquidating tangible assets (Gompers 1995; Knyazeva, A., Knyazeva, D. 2012). Thus, banks ask for lower collateral from the firms those possess a significant amount of tangible assets.

Considering the ownership (Ownership) structure of firms and the incidence of collateral, we find a positive significant result, which is opposite to our expectation. The result suggests that banks are taking restrictive measures in terms of holding collateral from concentrated firms. It could be possible that concentrated firm ownership increases the possibility of agency costs, as argued by Jensen and Meckling (1976). Additionally, risk-shifting behaviour may be more likely in concentrated firms due to individual holding power in the management of the firms. Steijvers et al. (2010) find that family firms pledge more collateral in comparison to non-family firms due to the free riding problem of family members in the business. Hence, this reasoning may also apply to our sample of firms, as SMEs are more likely to be managed and operated by individual or family members.

Our estimation result for female ownership (Female) of firms is positively associated with collateral in all regression specifications. This suggests that female-owned firms are more likely to provide collateral compared to male-owned firms in our sample countries. There can be a few explanations for this result. First, banks perceive female-owned firms as riskier because they often have less experience in business management and more attachment with the family than the business (Garwe, Fatoki 2012; Boyer, Blazy 2014). Second, female-owned firms usually lack a past business record and, hence, receive strict credit conditions from banks (Irwin, Scott 2010). Third, Alesina et al. (2013) report that female borrowers have less bargaining power than male borrowers, which may cause women borrowers to accept loans with higher collateral requirements. Finally, it could also be the fact that female owners in our sample of firms manage firms that require higher collateral. However, we did not examine this possibility in this paper, which could be an interesting topic for future research.

We did not find any effect of borrower experience (Experience) on the incidence of collateral. Therefore, we may say that borrower experience in Visegrad countries is not a determinant factor for banks while deciding for granting loans to a particular borrowers and asking for collateral. Our result is also aligned with the result of Duarte et al. (2017), where they did not find any significant effect of borrower experience in collateral requirements for SMEs.

According to our expectation, we find a positive effect of firm innovativeness (Innovation) on collateral requirements but the result is not statistically significant. We hypothesized that innovative firms are more information opaque in comparison to noninnovative firms and need to pledge more collateral to reduce information asymmetry. However, the insignificant results suggest that collateral constraints on innovative SMEs are no more than on non-innovative ones. Thus, innovation activities do not create borrowing constraints for SMEs at least in the form of higher collateral requirements. 
Table 4. Logistic regression on the presence of collateral

\begin{tabular}{|c|c|c|c|}
\hline Variable & Model 1 & Model 2 & Model 3 \\
\hline & Collateral (1/0); logit & Collateral $(1 / 0)$; logit & Collateral (1/0); logit \\
\hline \multicolumn{4}{|c|}{ Firm characteristics } \\
\hline Size & $0.007(0.003)^{*}$ & $0.002(0.007)^{*}$ & $0.007(0.004)^{* *}$ \\
\hline Age & $-0.001(0.016)^{* *}$ & $-0.013(0.034)$ & $-0.009(0.017)$ \\
\hline Audit & $0.307(0.251)$ & $0.348(0.481)$ & $0.085(0.262)$ \\
\hline Manufacturing & $-0.0368(0.382)^{*}$ & $-0.504(0.452)^{*}$ & $-0.230(0259)^{*}$ \\
\hline Ownership & $0.004(0.005)^{* *}$ & $0.002(0.009)^{*}$ & $0.004(0.005)^{*}$ \\
\hline Experience & $0.018(0.013)$ & $0.052(0.026)$ & $0.018(0.013)$ \\
\hline Female & $0.540(0.245)^{* *}$ & $0.568(0.474)^{* *}$ & $0.436(0.246)^{* *}$ \\
\hline Innovation & $0.057(0.246)$ & $0.455(0.447)$ & $0.186(0.252)$ \\
\hline Quality & $0.482(0.252)$ & $0.572(0.482)$ & $0.491(0.262)$ \\
\hline Crime & $0.025(0.262)^{* *}$ & $0.040(0.473)^{* *}$ & $0.065(0.265)^{* *}$ \\
\hline Liquidity & $0.008(0.003)$ & $0.006(0.005)$ & $0.011(0.003)$ \\
\hline \multicolumn{4}{|c|}{ Loan characteristics } \\
\hline Ln (LoanSize) & & $0.031(0.007)$ & \\
\hline LoanMaturity & & $0.008(0.006)^{*}$ & \\
\hline InterestRate & & $0.071(0.031)^{* *}$ & \\
\hline \multicolumn{4}{|c|}{ Lender market characteristics } \\
\hline City & & & $-0.486(0.306)^{*}$ \\
\hline $\mathrm{CR}$ & & & $0.022(0.010)^{* *}$ \\
\hline $\mathrm{BRc}$ & & & $-0.002(0.025)$ \\
\hline Constant & $-1.464(0.686)^{* * *}$ & $-0.404(1.024)$ & $-2.587(1.364)^{*}$ \\
\hline Observations & 430 & 126 & 430 \\
\hline Log-Likelihood & -474.083 & -141.17 & -468.908 \\
\hline Pseudo-R Square & 0.135 & 0.217 & 0.15 \\
\hline
\end{tabular}

Source: Authors' own estimation. Statistical significance at the $10 \%, 5 \%$ and $1 \%$ level indicated by *, ** and ***, respectively. Standard errors are in parentheses.

With respect to the borrower observed-risk hypothesis variables Quality, Crime and Liquidity, we find a significant result only in the case of crime, whereas quality and liquidity have an insignificant effect on collateral. The positive coefficients of crime and collateral suggest that firms with a track-record of losses due to theft, robbery, vandalism or arson must pledge more collateral due to their high-risk perception. Hence, in accordance with past literature, we provide evidence that when borrower quality is observable as risky, banks require more collateral (Berger, Udell 1990; Jimenez et al. 2006; Godlewski, Weill 2011; Hanedar et al. 2014; Duarte et al. 2017) to protect their loan portfolio (Blazy, Weill 2013). Thus, borrower observed-risk has a positive effect on collateral in the Visegrad countries. 
Table 3 (Model 2) reports the loan characteristic variables and their impact on the likelihood of pledging collateral. We find a positive result for all three loan characteristic variables - LoanSize, LoanMaturity and InterestRate - on the incidence of collateral. However, we find significant results for loan maturity and interest rates but insignificant results for loan size. The result suggests that loans with longer maturity are more likely to pledge collateral than short-term loans. It can be that long-term loans may induce risk-shifting behaviour in managers (Jensen, Meckling 1976). Long-term loans may also create moral hazard problems, provoking banks to ask for collateral (Duarte et al. 2016). Voordeckers and Steijvers (2006) find that long-term loans are collateralized with fixed assets in the Belgian market. Thus, longer maturity signals higher risk for banks and requires collateral safety to assure that the borrowers will not engage in any activities that is contradictory with the interest of the banks. The positive coefficients of interest rate with collateral are evidence that risky borrowers are required to provide more collateral and pay higher interest rates; hence, we show further evidence of the borrower observed-risk hypothesis (Bester 1985; Chan, Kanatas 1985; Brick, Palia 2007; Godlewski, Weill 2011). Hence, we can propose that there is an inter-relationship between observed credit quality, interest rates and collateral. It might be the case that when information asymmetry is low, a bank may screen its borrowers more thoroughly and any evidence of risky nature can induce banks to ask for more collateral and charge higher interest rates to compensate their investments. Therefore, the evidence from the Visegrad countries suggests that interest rates and collateral act as complementary rather than substitute of each other.

With respect to lender market characteristics, we find significant negative results for City and positive coefficients for $C R$. However, coefficients for $B R c$ are negative but not statistically significant. The negative coefficients for City suggest that firms located in the city are closer to the banks, which may reduce the probability of pledging collateral. It could be that a shorter distance may help in mitigating the information gap between the banks and borrowers. As a result, banks may require less collateral from borrowers that are closer to their branch. Therefore, our results also corroborate with the prior findings of Hainz et al. (2013) that firms located closer to banks are financed via screening and distant borrowers need to pledge collateral because of information opacity. It can be that a shorter distance increases bank efficiency in the loan screening process because the credit officer can travel to the firm more frequently and acquire firm-specific soft information, as asserted by Agarwal and Hauswald (2010). The positive coefficients of $C R$ suggest that firms in a concentrated market need to provide more collateral than in a competitive market. Therefore, we can say that in a concentrated market, banks may use their market power to increase collateral requirements for small businesses. Our results are in line with those of Duarte et al. (2017), who also find a positive effect of bank concentration on collateral. It might be that by asking for collateral, banks in a concentrated market could reduce their screening efforts and associated costs. Thus, as argued by Manove et al. (2001), concentration may increase the "lazy" behaviour of banks, as they rely more on collateral to provide small business loans. 


\section{Conclusions}

Collateral requirements on a loan contract are particularly significant for SMEs rather than the large firms because SMEs are information opaque and collateral can act as a signalling device for borrowers to show their credit quality, which can ease access to financing and strict loan conditions. Similarly, by asking for collateral, a bank can minimize its loss exposure in the event of loan default and provide protection from borrower moral hazards. Hence, collateral has important implications for both borrowers and lenders on a loan agreement. However, SMEs possess fewer assets that can be pledged as collateral and, hence, SMEs face credit rationing from banks. In this paper, we examine the determinants of collateral on SME financing in the context of four central European countries, or Visegrad countries (Czech Republic, Slovak Republic, Poland and Hungary). The data set was obtained from the European Bank for Reconstruction and Development (EBRD) and the World Bank (WB) Business Environment and Enterprise Performance Survey (BEEPS), wave V, which was conducted from 2012-2014. We also complemented the BEEPS survey data with indicators from the Beck et al. (2000), Global Financial Database. This paper investigates the incidence of collateral by focusing on three main areas: firm characteristics, loan specific variables and lender market characteristics.

Our results suggest that large firms, ownership concentration, firms owned by females and firms with a past business record of losses due to theft, robbery, vandalism or arson are more likely to pledge collateral on their borrowings. However, the probability of requiring collateral is lower for older and manufacturing firms, which may be due to lower information asymmetry. Therefore, we provide evidence that reduction of information asymmetry can play a significant role in alleviating collateral requirements for SMEs. The negative association between firm age, manufacturing firms and the incidence of collateral supports our claims. We show that firms affected by criminal activities are more likely to pledge collateral because of their high-risk perception. Hence, borrower observed-risk characteristics could induce collateral on a loan contract. Our results also support that the ownership concentration increases the likelihood of pledging collateral. Thus, banks perceive firms managed by the owner or owned by a few people as riskier due to risk-shifting behaviours of individuals and, hence, banks ask for more collateral to align the interest of the borrower with the interest of the banks. We also find evidence that firms owned by female borrowers are more likely to pledge collateral in comparison to male-owned firms. Therefore, we can infer that banks in our sample countries treat female-owned firms as riskier than those owned by their male counterparts.

We also find that loans granted for a longer period are more likely to be secured with collateral. Therefore, it may suggest that long-term loans are riskier than the short-term loans. Similarly, collateral requirements are higher for loans with higher interest costs. These results provide evidence that borrower observed credit quality is a main factor inducing collateral requirements on a loan contract.

It is also noticeable that firms located in the capital city are less likely to provide collateral on their loan contract. Therefore, it seems that shorter distance alleviates the 
information gap between the banks and borrowers. Finally, we find empirical evidence that banking concentration increases collateral requirements for SMEs. Thus, we can say that concentration is not ideal for SMEs to obtain loans with lower collateral, as in a concentrated market, a bank can exploit its market power to impose stringent collateral requirements.

By considering the significance our results, it is worth to mention that the current research brings several new insights in collateral based lending in the segment of SMEs. Such as, this paper examines the determinants of collateral by using a unique dataset that has not been used in any earlier research. Furthermore, unlike previous research, this paper not only shows empirical results considering the firm characteristics but also from the perspective of financial market structure and lending terms in a loan contract. We also show disadvantage for distant and female borrowers in collateral based lending which is quite scant in the past literature.

The results of the current paper provide a few implications for policy makers. First, taking effective measures to increase bank competition can create a level playing field for other banks and may reduce strict collateral requirements for SMEs. Second, banks can lower collateral requirements for female-owned firms, which can encourage more female entrepreneurs to access bank loans. Finally, regulators may take initiatives to reduce the interest rate for SMEs that can foster SME growth and therefore contribute to the economy. Further studies are required to understand the ratio of collateral to loan and the impact of market structures that induce a high ratio of collateral for SMEs. Similarly, this study has not analysed which type of collateral is preferable for SME loans - personal or business - hence, we leave that for future studies.

\section{Acknowledgement}

Ashiqur Rahman and Jaroslav Belas are thankful to the Internal Grant Agency of FaME TBU No. IGA/FaME/2017/010: Financial Constraints on Economic Activities, for financial support to carry out this research.

\section{References}

Agarwal, S.; Hauswald, R. 2010. Distance and private information in lending, The Review of Financial Studies 23(7): 2757-2788. https://doi.org/10.1093/rfs/hhq001

Alesina, A. F.; Lotti, F.; Mistrulli, P. E. 2013. Do women pay more for credit: evidence from Italy, Journal of European Economic Association 11: 46-66.

https://doi.org/10.1111/j.1542-4774.2012.01100.x

Ang, J. 1992. On the theory of finance for privately held firms, Journal of Entrepreneurial Finance 1(3): 185-203.

Ang, J.; Lin, J.; Tyler, F. 1995. Evidence on the lack of separation between personal and business risks among small businesses, Journal of Small Business Finance 4: 197-210.

Avery, R. B.; Bostic, R.; Samolyk, K. 1998. The role of personal wealth in small business finance, Journal of Banking and Finance 22: 1019-1061. https://doi.org/10.1016/S0378-4266(98)00016-8 Ayyagari, M.; Beck, T.; Demirgüç-Kunt, A. 2007. Small and medium enterprises across the globe, Small Business Economics 29: 415-434. https://doi.10.1007/s11187-006-9002-5 
Beck, T.; Demirgüc-Kunt, A.; Levine, R. 2000. A new database on financial development and structure, World Bank Econ Rev 14:597-605.

Beck, T.; Demirguc-Kunt, A.; Laeven, L.; Maksimovic, V. 2006. The determinants of financing obstacles, Journal of International Money and Finance 25: 932-952.

https://doi.org/10.1016/j.jimonfin.2006.07.005

Beck, T.; De La Torre, A. 2007. The basic analytics of access to financial services, Financial Markets, Institutions and Instruments 16(2): 79-117.

https://doi.org/10.1111/j.1468-0416.2007.00120.x

Business Environment and Enterprise Performance Survey (BEEPS). 2012-2014. [online], [cited January 2016]. Available from Internet: http://ebrd-beeps.com/

Belas, J.; Kljucnikov, A.; Vojtovic, S.; Sobekova-Majkova, M. 2015. Approach of the SME entrepreneurs to financial risk management in relation to gender and level of education, Economics and Sociology 8(4): 32-42. https://doi.org/10.14254/2071- 789X.2015/8-4/2

Belluchi, A.; Borisov, A.; Zazzaro, A. 2010. Does gender matter in bank-firm relationships? Evidence from small business lending, Journal of Banking and Finance 34: 2968-2984.

https://doi.org/10.1016/j.jbankfin.2010.07.008

Berger, A. N.; Udell, G. F. 1990. Collateral, loan quality and bank risk, Journal of Monetary Economics 25: 21-42. https://doi.org/10.1016/0304-3932(90)90042-3

Berger, A. N.; Udell, G. F. 1995. Relationship lending and lines of credit in small firm finance, Journal of Business 68(3): 351-381. https://doi.org/10.1086/296668

Berger, A. N.; Udell, G. F. 2002. Small business credit availability and relationship lending: the importance of bank organisational structure, The Economic Journal 112(477): 32-53.

https://doi.org/10.1111/1468-0297.00682

Berger, A. N.; Udell, G. F. 2006. A more complete conceptual framework for SME finance, Journal of Banking and Finance 30: 2945-2966. https://doi.org/10.1016/j.jbankfin.2006.05.008

Berger, A.; Espinosa-Vega, M. A.; Frame, W. S.; Miller, N. H. 2011. Why do borrowers pledge collateral? New evidence on the role of asymmetric information, Journal of Financial Intermediation 20: 55-70. https://doi.org/10.1016/j.jfi.2010.01.001

Berlin, M.; Butler, A. W. 2002. Collateral and competition. Working Paper No 02-22, Federal Reserve Bank of Philadelphia.

Besanko, D.; Thakor, A. 1987. Collateral and rationing: sorting equilibria in monopolistic and competitive credit markets, International Economic Review 28: 671-689.

https://doi.org/10.2307/2526573

Bester, H. 1985. Screening vs rationing in credit markets with imperfect information, American Economic Review 75(4): 850-885.

Blazy, R.; Weill, L. 2013. Why do banks ask for collateral in SME lending?, Applied Financial Economics 23(13): 1109-1122. https://doi.org/10.1080/09603107.2013.795272

Bolton Committee. 1971. Report of the committee of inquiry on small firms. Cmnd 4811, HMSO, London.

Boot, A. W.; Thakor, A. V.; Udell, G. F. 1991. Secured lending and default risk: equilibrium analysis, policy implications and empirical results, Economic Journal 101(406): 458-472.

https://doi.org/10.2307/2233552

Boyer, T.; Blazy, R. 2014. Born to be alive: the survival of innovative and non-innovative French micro-start-ups, Small Business Economics 42: 669-683.

https://doi.org/10.1007/s11187-013-9522-8

Brick, I. E.; Palia, D. 2007. Evidence of joint-ness in the terms of relationship lending, Journal of Financial Intermediation 16: 452-476. https://doi.org/10.1016/j.jfi.2007.01.001 
Carter, D. A.; McNulty, J. E.; Verbrugge, J. A. 2004. Do small banks have an advantage in lending? An examination of risk-adjusted yields on business loans at large and small banks, Journal of Financial Services Research 25: 233-252. https://doi.org/10.1023/B:FINA.0000020663.21079.d2 Carter, S.; Rosa, P. 1998. The financing of male and female-owned businesses, Entrepreneurship and Regional Development 10: 225-241. https://doi.org/10.1080/08985629800000013

Chakraborty, A.; Hu, C. X. 2006. Lending relationships in line-of-credit and nonline-of-credit loans: evidence from collateral use in small business, Journal of Financial Intermediation 15: 86-107. https://doi.org/10.1016/j.jfi.2005.07.002

Chan, Y. S.; Kanatas, G. 1985. Asymmetric valuations and the role of collateral in loan agreements, The Journal of Money Credit and Banking 17: 84-95. https://doi.org/10.2307/1992508

Cowling, M. 1999. The incidence of a loan collateralization in small business lending contracts: evidence from the UK, Applied Economics Letters 6: 291-293.

https://doi.org/10.1080/135048599353258

Daszkiewicz, N. 2014. Small and medium-sized enterprises in Visegrad countries towards internationalisation challenges in the European Union, Chapter 9 in A. Duréndez, K. Wach (Eds.). Patterns of business internationalisation in Visegrad countries - in search for regional specifics. Cartagena: Universidad Politécnica de Cartagena.

Degryse, H.; Van Cayseele, P. 2000. Relationship lending within a bank-based system: evidence from European small business data, Journal of Financial Intermediation 9: 90-109.

https://doi.org/10.1006/jin.1999.0278

Duarte, F. D.; Gama, A. P. M.; Esparanca, J. S. 2016. The role of collateral in the credit acquisition process: evidence from SME lending, Journal of Business Finance and Accounting 43(5): 693-728. https://doi.org/10.1111/jbfa.12207

Duarte, F. D.; Gama, A. P. M.; Esparanca, J. S. 2017. Collateral-based in SME lending, the role of business collateral and personal collateral in less developed countries, Research in International Business and Finance 39: 406-422. https://doi.org/10.1016/j.ribaf.2016.07.005

Fama, E. F.; Jensen, M. C. 1983. Separation of ownership and control, Journal of Law and Economics 26(2): 301-325. https://doi.org/10.1086/467037

Ferri, G.; Murro, P. 2015. Do firm odd couples exacerbate credit rationing, Journal of Financial Intermediation 24: 231-251. https://doi.org/10.1016/j.jfi.2014.09.002

Freel, M. S. 2007. Are small innovators credit rationed? Small Business Economics 28: 23-35. https://doi.org/10.1007/s11187-005-6058-6

Gama, A. P. M.; Duarte, F. D. 2015. Collateral and relationship lending in loan pricing: evidence from UK SMEs, WSEAS Transactions on Business and Economics 12: 21-35.

Garcia-Teruel, P. J.; Martınez-Solano, P.; Sanchez-Ballesta, J. P. 2014. Supplier financing and earnings quality, Journal of Business Finance \& Accounting 41(9-10): 1193-211.

https://doi.org/10.1111/jbfa.12090

Garwe, D. K.; Fatoki, O. 2012. The impact of gender on SME characteristics and access to debt finance in South Africa, Development Southern Africa 29(3): 448-461.

https://doi.org/10.1080/0376835X.2012.706040

Godlewski, C. J.; Weill, L. 2011. Does collateral help mitigate adverse selection? A cross-country analysis, Journal of Financial Services Research 40: 49-78.

https://doi.org/10.1007/s10693-010-0099-y

Gompers, P. 1995. Optimal investment, monitoring, and the staging of venture capital, Journal of Finance 50: 1461-1489. https://doi.org/10.1111/j.1540-6261.1995.tb05185.x

Grunert, J.; Norden, L. 2012. Bargaining power and information in SME lending, Small Business Economics 39: 401-417. https://doi.org/10.1007/s11187-010-9311-6 
Hainz, C.; Weill, L.; Godlewski, C. J. 2013. Bank competition and collateral: theory and evidence, Journal of Financial Services Research 44: 131-148. https://doi.org/10.1007/s10693-012-0141-3 Hall, B. H. 2010. The financing of Innovative firms, Review of Economics and Institutions 1: 1-30. https://doi.org/10.5202/rei.v1i1.4

Han, L.; Fraser, S.; Storey, D. J. 2009. The role of collateral in entrepreneurial finance, Journal of Business Finance and Accounting 36(3-4): 424-455.

https://doi.org/10.1111/j.1468-5957.2009.02132.x

Hanedar, E. Y.; Broccardo, E.; Bazzana, F. 2014. Collateral requirements of SMEs: the evidence from less developed countries, Journal of Banking and Finance 38: 106-121.

https://doi.org/10.1016/j.jbankfin.2013.09.019

Harhoff, D.; Korting, T. 1998. Lending relationships in Germany: empirical evidence from survey data, Journal of Banking and Finance 22(10): 1317-1353.

https://doi.org/10.1016/S0378-4266(98)00061-2

Hernandez-Canovas, G.; Martinez-Solano, P. 2006. Banking relationships: effects on debt terms for small Spanish firms, Journal of Small Business Management 44(3): 315-333.

https://doi.org/10.1111/j.1540-627X.2006.00174.X

Hsiao, Y. Z.; Chou, N. T. 2015. Owner characteristics and the cost of bank loan: evidence from small business [online], [cited 13 October 2016]. Available from Internet: http://papers.ssrn.com/ sol3/papers.cfm?abstract_id=2562981

Irwin, D.; Scott, J. M. 2010. Barriers faced by SMEs in raising bank finance, International Journal of Entrepreneurial Behaviour and Research 16(3): 245-259.

Jensen, M.; Meckling, W. 1976. Theory of the firm, managerial behaviour, agency costs and ownership structure, Journal of Financial Economics 5: 305-306.

https://doi.org/10.1016/0304-405X(76)90026-X

Jimenez, G.; Saurina, J. 2004. Collateral, type of lender and relationship banking as determinants of credit risk, Journal of Banking and Finance 28: 2191-2212.

https://doi.org/10.1016/j.jbankfin.2003.09.002

Jimenez, G.; Salas, V.; Saurina, J. 2006. Determinants of collateral, Journal of Financial Economics 81: 255-281. https://doi.org/10.1016/j.jfineco.2005.06.003

Jimenez, G.; Salas, V.; Saurina, J. 2009. Organizational distance and use of collateral for business loans, Journal of Banking and Finance, 33: 234-243.

https://doi.org/10.1016/j.jbankfin.2008.07.015

Korab, P.; Pomenkova, J. 2014. Financial crisis and financing constraints of SMEs in Visegrad countries [online], [cited 20 January 2017]. WIFO working papers, No (485). Available from Internet: https://www.econstor.eu/handle/10419/129034

Knyazeva, A.; Knyazeva, D. 2012. Does being your bank's neighbour matter?, Journal of Banking and Finance 36: 1194-1209. https://doi.org/10.1016/j.jbankfin.2011.11.011

Lee, N.; Sameen, H.; Cowling, M. 2015. Access to finance for innovative SMEs since the financial crisis, Research Policy 44: 370-380. https://doi.org/10.1016/j.respol.2014.09.008

Leeth, J. D.; Scott, J. A. 1989. The incidence of secured debt: evidence from the small business community, J. Financial Quant. Anal. 24(3): 379-394. https://doi.org/10.2307/2330818

Lehmann, E.; Neuberger, U. 2001. Do lending relationship matter? Evidence from bank survey data in Germany, Journal of Economic Behaviour and Organization 45: 339-359.

https://doi.org/10.1016/S0167-2681(01)00151-2

Lenka, S.; Oldrich, H.; Belas, J.; Jiri, M. 2014. Perception of small and medium entrepreneurship in the Czech Republic, Journal of Competitiveness 4: 41-49.

https://doi.org/10.7441/joc.2014.04.03 
Leon, F. 2015. Does bank competition alleviate credit constraints in developing countries?, Journal of Banking and Finance 57: 130-142. https://doi.org/10.1016/j.jbankfin.2015.04.005

Manove, M.; Padilla, A.; Pagano, M. 2001. Collateral vs project screening: a model of lazy bank, RAND Journal of Economics 32: 726-744. https://doi.org/10.2307/2696390

Menkhoff, L.; Neuberger, D.; Suwanaporn, C. 2006. Collateral based lending in emerging markets: evidence from Thailand, Journal of Banking and Finance 30: 1-21.

https://doi.org/10.1016/j.jbankfin.2004.12.004

Menkhoff, L.; Neuberger, D.; Rungruxsirivorn, O. 2012. Collateral and its substitutes in emerging markets lending, Journal of Banking and Finance 36: 817-834.

https://doi.org/10.1016/j.jbankfin.2011.09.010

Moore, I.; Garnsey, E. 1993. Funding for innovation in small firms: the role of government, Research Policy 22: 507-519. https://doi.org/10.1016/0048-7333(93)90015-A

Myres, S. C. 1977. Determinants of corporate borrowing, Journal of Financial Economics 5(2): 147-175. https://doi.org/10.1016/0304-405X(77)90015-0

Neuberger, D.; Rathke-Doppner, S. 2015. The role of demographics in small business loan pricing, Small Business Economics 44: 411-424. https://doi.org/10.1007/s11187-014-9602-4

Ortiz-Molina, H.; Penas, M. F. 2008. Lending to small businesses: the role of loan maturity in addressing information problems, Small Business Economics 30: 361-383.

https://doi.org/10.1007/s11187-007-9053-2

Petersen, M. A.; Rajan, R. G. 2002. Does distance still matter? The information revolution in small business lending, The Journal of Finance 57: 2533-2570.

https://doi.org/10.1111/1540-6261.00505

Rahman, A.; Rahman, M. T.; Kljucnikov, A. 2016. Collateral and SME financing in Bangladesh: an analysis across bank size and bank ownership types, Journal of International Studies 9(2): 112-126. https://doi.org/10.14254/2071-8330.2016/9-2/8

SAFE - Survey on the Access to Finance in the Euro Area 2015. European Central Bank. [online] [cited 25 January 2017]. Available from Internet: https://www.ecb.europa.eu/stats/money/surveys/ sme/html/index.en.html

Steijvers, T.; Voordeckers, W.; Vanhoof, K. 2010. Collateral, relationship lending and family firms, Small Business Economics 34: 243-259. https://doi.org/10.1007/s11187-008-9124-z

Stiglitz, J. E.; Weiss, A. 1981. Credit rationing in markets with imperfect information, The American Economic Review 71: 393-410.

Tirole, J. 2010. The theory of corporate finance. Princeton, NJ. USA: Princeton University Press. Voordeckers, W.; Steijvers, T. 2006. Business collateral and personal commitments in SME lending, Journal of Banking and Finance 30: 3067-3086.

https://doi.org/10.1016/j.jbankfin.2006.05.003

Ashiqur RAHMAN is a PhD candidate in Finance at Tomas Bata University in Zlin, Czech Republic. Before that, he has received his Msc Finance at the University of Strathclyde, Glasgow, Scotland, UK. He has research interests in SME Finance, Corporate Governance, and Entrepreneurship.

Jaroslav BELAS, PhD, is Full Professor. He is a renowned expert in commercial banking and risk management of SMEs. He worked in the banking sector of Slovakia from 1993 to 2001. In academic field, he has worked at the University of Economics in Bratislava and the Pan European University in Bratislava. He is currently at Tomas Bata University in Zlin, Faculty of Management and Economics. $\mathrm{He}$ is an author of nine monographs; the results of the research activities have been outputted through 70 various scientific works that have been published in prestigious journals. He is a member of the Scientific Council of Pan European University in Bratislava and the Scientific Council of Georg Žilina publisher in Slovakia. Currently he manages five scientific projects. 
Tomas KLIESTIK, PhD, is Full Professor. He is an expert in application of quantitative mathematical statistical methods in financial management of companies and methods of risk quantification and diversification. He is currently head of the Department of Economics at the Faculty of Operation and Economics of Transport and Communications, University of Zilina. He is an author of 4 monographs; results of his research activities have been published in more than 120 various scientific works from which 31 are indexed in the Web of Science database. His works have recorded more than 450 citations from which 215 are indexed in Web of Science database and his current H-index is 8. He is a member of the Scientific Council of the Faculty of Economics and Management, Slovak University of Agriculture in Nitra; Scientific Council of the Faculty of Operation and Economics of Transport and Communications, University of Zilina and Academic Board of School of Expertness and Valuation, Institute of Technology and Business in České Budějovice. Currently he manages one scientific project financed by Slovak Research and Development Agency and one scientific project financed by Scientific Grant Agency of the Ministry of Education, Science, Research and Sport of the Slovak Republic and Slovak Academy of Sciences.

Ladislav TYLL, PhD, is an Assistant Professor at the University of Economics, Prague - Faculty of Business Administration. His research is focused on International Strategy and Business as well as Entrepreneurship primarily in CEE region. Most of the research topics are business related and usually designed as made to order by corporate partners. Besides his academic career, he works as a business consultant. 